\title{
FERTILIZER REQUIREMENTS OF MAIROA ASH SOILS
}

\author{
J. KarlovsKy
}

Ruakura Soil Research Station, Hamilton

\begin{abstract}
Field experiments conducted on soils derived from Mairoa ash beds showed that they respond markedly to phosphate and require heavy phosphate applications for the maintenance of high pasture production. Thus, on Dunmore and Otorohanga silt loam annual rates of 375 and $750 \mathrm{~kg} / \mathrm{ha}$ of superphosphate were needed for maintenance of 85 and $95 \%$ of maximum production, respectively. After cessation of phosphate dressings, the decline in pasture production was dramatic, even on plots with high initial dressings. In cases where soil test values for potassium were below 10 , moderate and statistically significant potash responses were measured. Small annual applications of carbonate of lime $(312 \mathrm{~kg} / \mathrm{ha})$ gave a slight but statistically non-significant increase in production $(3 \%)$. However, heavier applications (625 and $1250 \mathrm{~kg} / \mathrm{ha}$ ) significantly decreased production on Dunmore silt loam, at $\mathrm{pH}$ of 5.8 , after the sixth and seventh annual applications.
\end{abstract}

\section{INTRODUCTION}

MANY soILS of 'southern Waikato land northern King Country are derived from what has been commonly called Mairoa ash. Recent work indicates that this is not a single shower but a series of rhyolitic and andesitic showers derived from eruptions near Rotorua and Taupo. In southern King Country some of the ash is possibly derived from Taranaki volcanoes (G. E. Orbell, pers. comm.). As these soils have a high content of aluminium and iron-rich clays, they have a considerable propensity for fixing phosphate. Their potassium status is such that, under intensive farming, applications of potash are needed, responses becoming more marked with time.

\section{EXPERIMENTAL}

Results of seven experiments conducted by the writer on Mairoa ash are given in this paper. Two trials were established on Dunmore silt loam, testing phosphate and lime requirements, three trials on Otorohanga silt loam studying phosphate and potash needs, and two trials on Ohaupo silt loam investigating the critical soil test level for potassium. Trial No. 5 (Table 1) 
was conducted under common grazing and production was measured by taking seasonal outs; all other trials were under "mowing and clippings returned" management. They were run from two to seven years.

\section{RESULTS}

\section{P hosphate Responses}

On Dunmore silt- loam where previously phosphate topdressing had been low (250 kg aerial superphosphate/ha/yr) and the average soil $\mathrm{P}$ test value was below 2 , responses were very marked. Over a period of seven years, production on untopdressed plots gradually declined from 67 to $40 \%$ of the maximum, the average production on untopdressed plots over a seven-year period being slightly below $50 \%$ of the maximum (Fig. 1). A low annual application of $188 \mathrm{~kg}$ superphosphate/ha yielded on the average $72 \%$ of the maximum, while 375 and $750 \mathrm{~kg}$ annual dressings of superphosphate yielded 85 and $95 \%$ of the maximum, respectively.

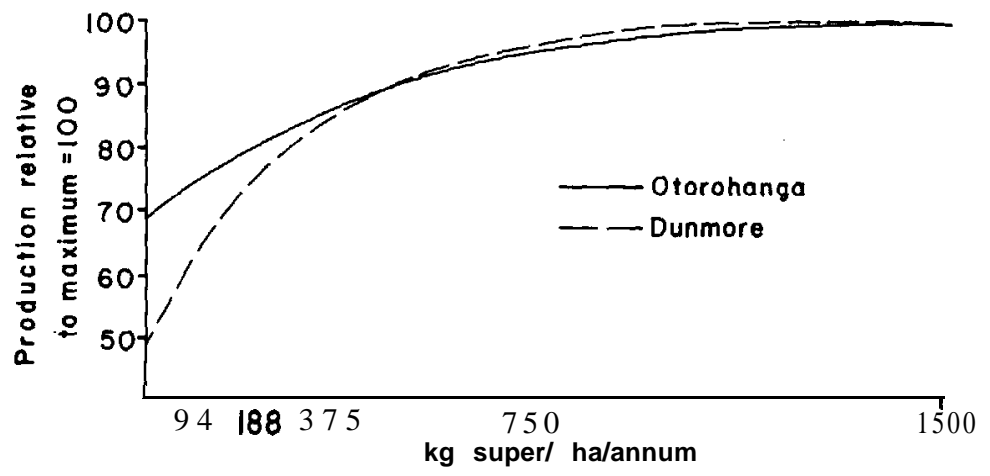

FIG. 1: Dry matter production to maximum $=100$ on Dunmore and Otorohanga silt loam.

On Otorohanga silt loam where annual rates of 500 to $625 \mathrm{~kg} /$ ha of phosphate fentilizers had been used and the soil $\mathrm{P}$ test value was approximately 4 , marked responses to phosphate were still apparent but the production on untopdressed plots was considerably higher than on Dunmore silt loam (Fig. 1) and was on the average $68 \%$ of the maximum. Light 'annual applications of $188 \mathrm{~kg}$ superphosphate/ha yielded on the average $78 \%$, while 375 land $750 \mathrm{~kg} / \mathrm{ha}$ rates maintained the production at approximately 85 and $95 \%$ of the maximum, respectively. There- 


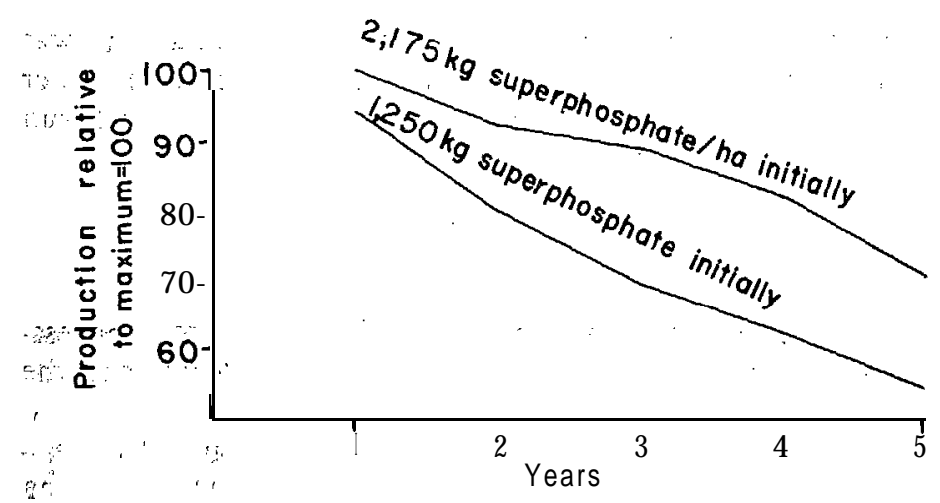

Fís. -2: Decline in pasfure production after cessation of fopdressing on $\therefore \quad \because: \quad$ O Oforohanga silt loam.

$r$.

fore relative production on both soil types was the same when these. were topdressed with $375 \mathrm{~kg}$ superphosphate or more per hectare.

On these soils there was a dramatic decline in pasture production after suspension of phosphate dressings. Thus, in a tribal established on a very low phosphate testing Otorohanga silt loam increasing amounts of phosphate from 310 to $3100 \mathrm{~kg}$ superphosphate equiv./ha were used initially. There was a rapid decline in production on plots treated in the first year with 1250 and $2175 \mathrm{~kg}$ superphosphate equiv./ha (Fig. 2). During the four years the yields declined to 55 and $71 \%$ of the maximum, respectively, on the above treatments.

\section{PotA sh Responses}

Available potassium levels on soils derived from Mairoa ash are lower than those derived from sedimentary rocks and Hamil-

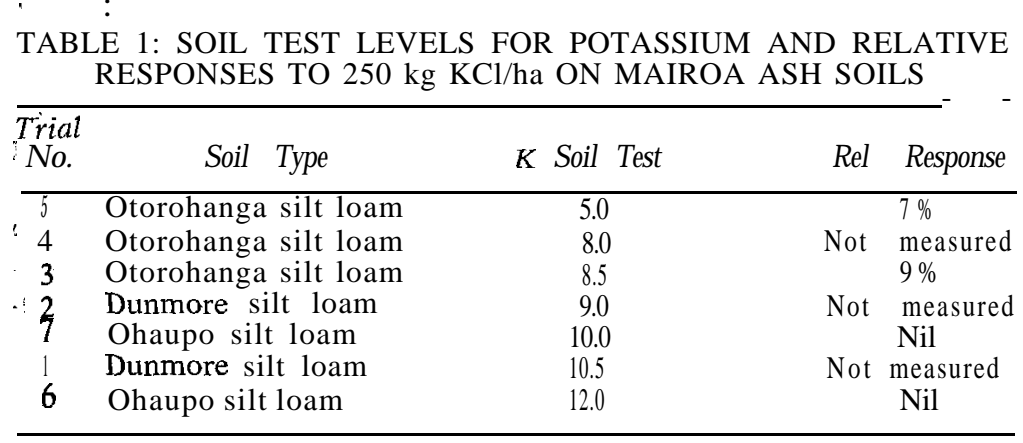


ton ash, and the range of soil test values from the experimental sites was from 5 to 12 (Table 1).

Potash responses measured in four out of the eight trials were moderate and statistically significant where the soil test values were 5 and 8.5. No responses were obtained in two other trials where values were 10 and 12 . These results indicate that the critical soil test level for potassium is between 8 and 10 and that when the test declines below 10 the soil cannot supply adequate potassium for high pasture production.

\section{Lime Responses}

Over the years Departmental trials conducted on ash soils, including Mairoa ash, have shown negligible responses to lime. However, no precise trials measuring total annual responses to lime have been conducted on these soils with the exception of one on Dunmoce silt loam, which showed a small (3\%) increase to light annual dressings of $312 \mathrm{~kg}$ carbonate of lime/ha and a significant 'depression after the sixth and seventh annual applications of 625 and $1250 \mathrm{~kg}$ carbonate of lime/ha as shown in Table 2.

TABLE 2: EFFECT OF REPEATED ANNUAL APPLICATIONS OF LIME ON PASTURE DRY MATTER PRODUCTION ON DUNMORE SILT LOAM

\begin{tabular}{ccc}
\hline Treatment & $\begin{array}{c}\text { kg Dry } \\
\text { 6th }\end{array}$ Year & $\begin{array}{c}\text { Matter and } \\
\text { 7th Year }\end{array}$ \\
\hline No lime & $7235(98) \mathrm{abA}$ & $8520(100) \mathrm{aA}$ \\
$312 \mathrm{~kg}$ Carbonate of lime/ha & $7400(100) \mathrm{aA}$ & $8390(98) \mathrm{aAB}$ \\
$625 \mathrm{~kg}$ Carbonate of lime/ha & $6720(91) \mathrm{bcA}$ & $7480(88) \mathrm{bBC}$ \\
$1250 \mathrm{~kg}$ Carbonate of lime/ha & $6530(88) \mathrm{cA}$ & $7120(84) \mathrm{bC}$ \\
\hline
\end{tabular}

Treatments with no letter in common differ significantly; capitals for $1 \%$, small letters for $5 \%$.

In the first five years of the trial, the lime depression occurred mainly on no $\mathrm{P}$ and light $\mathrm{P}$ treatments; however, in the sixth and seventh year the depression was recorded also on heavy P treatments. There is a possibility that the depression in yields was caused by a lime-induced Mn deficiency as lime additions reduced drastically $\mathrm{Mn}$ plant content to $20 \mathrm{ppm}$ in one cut taken in the sixth year. During (1972) reports that in Canterbury unnecessary liming has contributed to manganese deficiency in wheat. Also the plant magnesium concentration was decreased 
significantly by lime additions in 7 out of 9 cuts analysed. Boron plant uptake has not been affected by lime additions.

Recently Field Research Section of MAF established a series of mowing lime 'trials on Mairoa ash soils in which cuts are being taken in spring and autumn when the responses to lime are most likely to occur. So far responses have been obtained in three out of eight trials in autumn only.

\section{NUTRIENT REQUIREMENTS}

\section{Phosphate REQUiRements}

In order to determine optimum rates of phosphate, it is necessary to calculate the additional dry matter increase required at the top part of the production curve to pay for an additional unit of fertilizer together with the corresponding additional non-fertilizer cost. As the cost of fertilizer is known, it is necessary to determine only the associated non-fertilizer costs, or the ratio of fertilizer to non-fertilizer costs. After a close examination of the relevant data, the above ratio was taken as 1: 1 (Karlovsky, 1969). On the basis of present prices of agricultural products the value of $100 \mathrm{~kg}$ herbage DM increase (at $80 \%$ utilization) has been calculated at $\$ 3.50$ under dairy farming, $\$ 2.50$ under beef cattle "farming and $\$ 1.50$ under mixed sheep cattle farming. The price of superphosphate for this calculation was taken at $\$ 30.00 /$. Hence the dry matter increments necessary to pay for $50 \mathrm{~kg}$ or $1 \mathrm{cwt}$ or superphosphate are 85,120 and $200 \mathrm{~kg}$ under dairy, beef cattle, and mixed farming, respectively. If one assumes that the average maximum production on Mairoa ash soils is $11200 \mathrm{~kg} \mathrm{DM} / \mathrm{ha} / \mathrm{yr}$ then under dairy farming, applications of $750 \mathrm{~kg} / \mathrm{ha}$ are the optimum, amounts on both Dunmore and Otorohanga soils, as calculated from Fig. 1. Under beef cattle and mixed farming, 650 and $400 \mathrm{~kg} / \mathrm{ha}$ of superphosphate, respectively, are optimum applications on both soil types. The optimum application is the amount beyond which an increase becomes uneconomic. However, it is of no use producing $95 \%$ of the maximum with annual topdressings of $750 \mathrm{~kg}$ superphosphate/ha if $85 \%$ obtainable with $375 \mathrm{~kg} / \mathrm{ha}$ would be sufficient to feed stock 'adequately. Hence it is always necessary to consider the number of stock carried on the farm and calculate the proportion of maximum production necessary for adequate feeding of the stock present. Table 3 gives approximate pasture yields and carrying capacity under regular annual topdressing with phosphate. This is similar to that given by During (1972). 
TABLE 3: PASTURE YIELDS UNDER ANNUAL TOPDRESSING WITH SUPERPHOSPHATE AND APPROXIMATE CARRYING CAPACITY ON MAIROA ASH SOILS

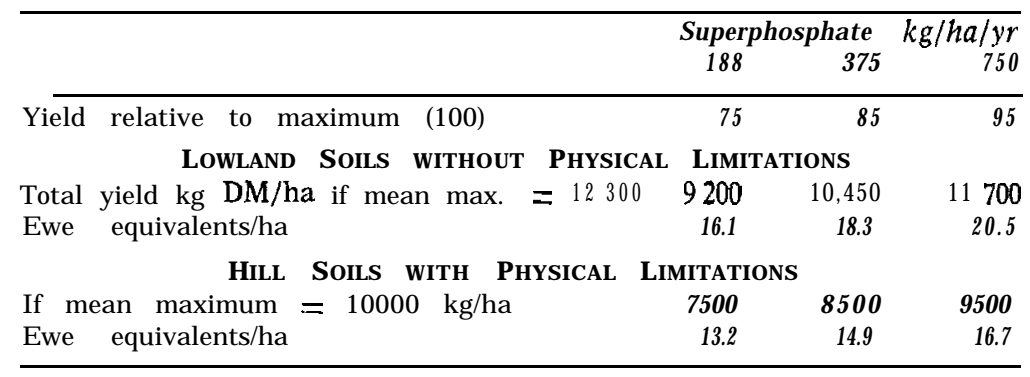

Table 3 shows that farmers carrying only 13 e.e./ ha on hill soils or 16 e.e./ha on lowlands (2 dairy cows/ha) need only about $188 \mathrm{~kg}$ superphosphate/ha/yr, but, at high stocking rates. heavy dressings of 500 to 700 superphosphate/ha/yr are needed.

\section{Potasu Requirements}

If the potassium soil test level is above 10, the soil supply of potash is sufficient for maintenance of high pasture production. If, however, soil $\mathrm{K}$ status falls below this level, potash applications become necessary for maintenance of high pasture production.

Potash requirements depend on the type of farming and on management. Under intensive dairy farming, $180 \mathrm{~kg} \mathrm{KCl} / \mathrm{ha} / \mathrm{yr}$ are required to compensate for losses suffered by soil through leaching and removal of potassium outside the grazing area. Annual applications of $120 \mathrm{~kg} / \mathrm{ha}$ are judged to maintain a medium potassium output of about $250 \mathrm{~kg} \mathrm{~K} / \mathrm{ha}$ - i.e., about $10000 \mathrm{~kg} \mathrm{DM} / \mathrm{ha}$ but applications of $60 \mathrm{~kg} / \mathrm{ha}$ under dairy farming are adequate only for sustenance of low pasture production.

On beef cattle and sheep farms, potash maintenance requirements are lower than on dairy farms simply because less is removed in excrements voided otherwise than on pasture. Annual applications of 120,80 and $40 \mathrm{~kg} \mathrm{KCl} /$ ha should be adequate for maintenance of high, medium and low pasture production, respectively. If the carrying capacity is below $13 \mathrm{e.e} / \mathrm{ha}$, then little or no potash is needed since less than $7500 \mathrm{~kg} \mathrm{DM} / \mathrm{ha}$ are required, to feed the stock, and this can be produced without the addition of potash provided the soil supply of available potassium is satisfactory (soil test value not below 4). 
The price of muriate of potash, including spreading costs, is at present approximately $\$ 55 / \mathrm{r}$. Hence the following increments in pasture production are needed for an economic return: 160,220 and $370 \mathrm{~kg}$ dry matter for the use of $50 \mathrm{~kg}$ or $1 \mathrm{cwt}$ $\mathrm{KCl}$ under dairy, beef cattle and mixed farming, respectively.

\section{LIME REQUIREMENTS}

To lime or not to lime? That is the $\$ 64$ question. Although between 1 and 1.5 million tonnes of carbonate of lime, costing farmers $\$ 10$ to $\$ 15$ million, are being used annually on New Zealand grasslands, not enough information is available on the effect of lime on total annual pasture production. Further, there is practically no information on its effect on livestock production on many soils, especially ash soils, and hill country in general. During (1972) states that almost no work has been done on liming hill country where knowledge on this subject is particularly important since the spreading cost there is very high.

Owing to lack of information on lime needs, many farmers are using lime on any soil type even with high $\mathrm{pH}$ values. Recently the writer sail-sampled several farms on which lime is being used and found that an the majority of paddocks $\mathrm{pH}$ was well over 6 , with $\mathrm{Ca}$ values between 10 and 15 . Under these conditions it is unlikely that there could be any increase in pasture production from lime additions, yet farmers are convinced that liming has had a beneficial effect on their livestock. Since the mineral content of unlimed pastures on the soils tested (Hamilton c-lay loam and Horotiu sandy loam) is within the normal healthy range for both plant and animal nutrition, an effect of liming on animal production would not be expected. Actually, in a thorough lime trial carried out over a period of 20 years under sheep grazing on Hamilton clay loam, at a comparatively low $\mathrm{pH}$ of 5.5 , liming has slightly decreased the livestock production by $34 \mathrm{~kg} \mathrm{LW} / \mathrm{ha} / \mathrm{yr}$.

The only experiment investigating the effect of lime an livestock production on a soil related to Meiroa ash soils is that on Stratford ash in Taranaki. So far, over a period of one year, there has not been any beneficial effect from lime either on pasture production or livestock health and production.

From experimental evidence available to date it appears that liming of pasture-lands with $\mathrm{pH}$ values above 5.5 is not economic. However, more thorough field experiments investigat- 
ing the effects of lime not only on pasture production but also on pasture nutritive value and animal health and production are urgently needed for the determination of lime requirements on different soil types.

\section{Requirements OF Other Nutrients}

So far no trace element, magnesium, or sulphur deficiencies have been recorded for pastures on Mairoa ash soils. However, boron at the rate of $17 \mathrm{~kg} / \mathrm{ha}$ should be broadcast for swedes or turnips (During, 1972).

\section{CONCLUSION}

'Experimental evidence has shown that Mairoa ash soils require heavy applications of phosphate for maintenance of high pasture production - i.e., approximately 500 and $750 \mathrm{~kg}$ superphosphate/ha for maintenance of 90 and $95 \%$ of maximum production. After cessation of phosphate topdressing, the decline in production is very rapid and therefore phosphate should be applied annually on these soils. The quantity of phosphate should be governed by the number of stock available on the farm, which should be the criterion for the desired or necessary percentage of the maximum pasture production. Potash is not needed if the soil test value is above 10. If the soil test falls below this level, potassium' requirements will depend on the type and intensity of farming land will vary from 0 to $188 \mathrm{~kg} / \mathrm{ha}$ of muriate of potash. Field experiments measuring the effect of lime on livestock production are urgently needed in order to determine whether lime is required on Mairoa ash soils. Magnesium, sulphur and trace element deficiencies have not yet been recorded on this soil under grassland.

\section{REFERENCES}

During, C., 1972: Fertilisers and Soils in New Zealand Farming, 2nd ed., pp. 12, 15, 209, 210: Government Printer, Wellington. Karlovsky, J.. 1969: Final R eport FAO/UNDP Special Fund Project No. 121, p. 46. FAO, Rome. 